\title{
Removal of Heavy Metals from Pharmaceutical Industrial Wastewater Effluent by Combination of Adsorption and Chemical Precipitation Methods
}

\author{
Tope Babatunde Ibigbami ${ }^{1, ~ *, ~ F o l a s e g u n ~ A n t h o n y ~ D a w o d u ~}{ }^{1}$, Olayinka John Akinyeye ${ }^{2}$ \\ ${ }^{1}$ Department of Chemistry, Faculty of Science, University of Ibadan, Ibadan, Nigeria \\ ${ }^{2}$ Engineering Materials Research Department, Nigerian Building and Road Research, Institute, Sango Ota, Nigeria
}

Email address:

tbabs04@gmail.com (T. B. Ibigbami)

\section{To cite this article:}

Tope Babatunde Ibigbami, Folasegun Anthony Dawodu, Olayinka John Akinyeye. Removal of Heavy Metals from Pharmaceutical Industrial Wastewater Effluent by Combination of Adsorption and Chemical Precipitation Methods. American Journal of Applied Chemistry. Vol. 4, No. 1, 2016, pp. 24-32. doi: 10.11648/j.ajac.20160401.15

\begin{abstract}
The removal of heavy metals from our environment especially industrial effluents is now shifting from the use of conventional adsorbents to the use of chemical precipitation. The presence of heavy metals in the environment is a major concern because of their toxicity, bioaccumulating tendency, and threat to human life and the environment. The main objective of this research is to study the effectiveness of the combination of hydrogen peroxide and activated bentonite clay in the removal of heavy metal ions from pharmaceutical industrial effluent. About $13.790 \mathrm{mg} / \mathrm{lof} \mathrm{Fe}, 1.650 \mathrm{mg} / \mathrm{lof} \mathrm{Zn}$ and 2.000 $\mathrm{mg} / \mathrm{l}$ of $\mathrm{Ni}$ were detected in the digested sample and batch removal of heavy metals such as $\mathrm{Fe}, \mathrm{Zn}$ and $\mathrm{Ni}$ from industrial wastewater effluent under different experimental conditions using hydrogen peroxide as precipitating agent in combination with activated bentonite clay as adsorbent. Appreciable differences in the level of heavy metals concentration were observed based on $\mathrm{pH}$ effect. The result shows higher effectiveness relatives to other treatments formulated for the effluent treatment such as Alum precipitation effect, effect of hydrogen peroxide concentration dose, contact time effect and temperature effect. Removal of heavy metals in effluent was optimum at $\mathrm{pH} 10$ for zinc $(\mathrm{Zn})$ and nickel $(\mathrm{Ni})$ and at $\mathrm{pH} 8$ for iron $(\mathrm{Fe})$, at temperature of $50^{\circ} \mathrm{C}, 0.75 \%$ hydrogen peroxide concentration dose and 100 mins holding time, reducing the amounts from 13.790 to $1.436 \mathrm{mg} / \mathrm{l}$ of $\mathrm{Fe}$, while 1.650 to $0.127 \mathrm{mg} / \mathrm{l}$ of $\mathrm{Zn}$ and 2.000 to $0.115 \mathrm{mg} / \mathrm{l} \mathrm{of} \mathrm{Ni}$ respectively. The percentage differences in concentration for the heavy metals removal in industrial wastewater are as follows: $\mathrm{Fe}(89.58 \%), \mathrm{Zn}(92.30 \%)$ and $\mathrm{Ni}$ (94.22\%). The result showed high level of $\mathrm{Zn}$ and $\mathrm{Ni}$ generated from this pharmaceutical industry is above $1 \mathrm{mg} / \mathrm{FEPA}$ and WHO standard but only Fe showed low level concentration compared to $20 \mathrm{mg} / \mathrm{l} \mathrm{FEPA}$ and WHO standard in this study. This study reveals the need for enforcing adequate effluent treatment methods before their discharge to surface water to reduce their potential environmental hazards.
\end{abstract}

Keywords: Heavy Metals, Pharmaceutical Effluent, Hydrogen Peroxide, Activated Bentonite Clay

\section{Introduction}

Environmental protection and rational use of natural resources and other industrial raw materials has become a very important sphere of mankind's advancement in the 20th century. Mankind's demand for resources and raw materials has increased the ecological and economic contradictions in the industries (Sen and Chakrabaty., 2009). This wide spread industrialization in urban areas has drastically reduced land area for waste disposal. Disposal of untreated industrial and domestic wastes into the environment affects both soil and ground water quality. Soil and streams have been used for multivarious purposes including waste disposal.

The industrial effluents consist of organic compounds along with inorganic complexes and other non-biodegradable substances. These pollutants not only alter the quality of ground water and soil but also pose serious problems threats to public health and/or affect the aesthetic quality of potable water. (Karthikeyan et al., 2010). According to World Health Organization (WHO), the metals of most immediate concern are chromium, zinc, iron, mercury and lead (WHO, 2010) and Maximum allowed limits for contaminants in "treated" wastewater are enforced in developed and many developing 
countries (Deng et al., 2003). The effluents discharge by different industries contain a high range of physical and chemical parameter like Temperature, $\mathrm{pH}$, Conductivity, Hardness, Alkalinity, Oxygen demand, Total suspended solid, Nitrate, Nitrite, Cations and Anions. The Environmental contamination with heavy metals is a consequence of technological and industrial advances (Davydova 2005; Wong et al., 2006). The principal problem associated with this anthropogenic contamination is toxicity against all living organisms, in particular, humans (Chapman et al. 2003; Florea and Büsselberg 2006; Sharma and Agrawal 2005). "Heavy metals" is a general collective form applying to the group of metals with an atomic density greater than $6 \mathrm{gkm}^{3}$. It is widely recognized and usually applied to the elements such as lead $(\mathrm{Pb})$, chromium $(\mathrm{Cr})$, copper $(\mathrm{Cu})$, manganese $(\mathrm{Mn})$, nikel $(\mathrm{Ni})$, cadmium $(\mathrm{Cd})$, and zinc $(\mathrm{Zn})$ etc which are commonly associated with pollution and toxicity problems (Morais et al., 2012). Some of the elements in this group are required by most living organisms in small for normal healthy growth, but excess concentration causes toxicity. Heavy metals cannot be degraded or destroy and they enter our bodies via food, drinking, water and air. As trace elements, some heavy metals are essential to maintain the metabolism of the human body but at higher concentration they can lead to poisoning. Heavy metals are dangerous because they tend to bioaccumulate and bioconcentrate in living tissue and biomagnify as it moves through the trophic levels (Sridhara et al., 2008). It is therefore, essential and important to remove or reduce the presence of these inorganic contaminants in order to diminish the possibility of uptake by plants, animals, and humans and eventual accumulation in the food chain and also to prevent them from contaminating surface and groundwater by dissolution or dispersion (Kabata-Pendias 2001; McLaughlin et al. 2000). To restore the heavy metal contaminated soil, tremendous expenses and time are required for complete remediation. The treatment of contaminated waters is as diverse and complicated as the operation from which it comes. A number of conventional treatment technologies have been considered for treatment of wastewater contaminated with heavy metals. Previous investigations on the removal of heavy metals from wastewater (Howari and Garmoon, 2003; Shwarts and Ploethner, 1999; El-Awady and Sami, 1997) suggest that systems containing calcium in the form Calcium oxide or Calcium trioxocarbonate (iv) and carbonates in general, are particularly effective in the removal of heavy metals from wastewater. Some of the conventional techniques for removal of metals from industrial wastewater include chemical precipitation, adsorption, solvent extraction, membrane separation, ion exchange, electrolytic techniques, coagulation/flotation, sedimentation, filtration, membrane process, biological process and chemical reaction (Blanco et al., 1999; Blanchard et al., 1984; Gloaguen and Morvan, 1997; Jeon et al., 2001; Kim et al., 1998; Lee et al., 1998; Mofa, 1995; Lujan et al., 1994; Gardea-Torresdey et al., 1996, Rai et al., 2002). Each method has its merits and limitations in application but Chemical treatment of industrial wastewater is preferable since industrial wastewaters are frequently complex, high in pollutant load and often containing materials toxic or resistant to the organisms on which biological processes depend. Also, chemical treatment systems are more predictable and inherently more subject to control by simple technique and chemicals are usually relatively tolerant to temperature changes. The use of hydrogen peroxide has gained much popularity, $\mathrm{H}_{2} \mathrm{O}_{2}$ is a powerful oxidizer that looks like water in its appearance, chemical formula and reaction products. Despite its power, it is a versatile oxidant which is both safe and effective. It is one of the most powerful oxidizers known, stronger than chlorine, chlorine dioxide, and potassium permanganate, and through catalysis, $\mathrm{H}_{2} \mathrm{O}_{2}$ can be converted into hydroxyl radical $\left(\mathrm{OH}^{-}\right)$with reactivity second only to fluorine. Likewise adsorption has been recognized as a potential technology for the removal of heavy metals and other pollutants from waste water in comparison to other physical, chemical and biological methods available for the treatment of wastewater (Abasi et al., 2011), adsorption is the most preferred technique due to simple and flexible design and easy operation. The adsorption process may generate little or toxic pollutants and involve low initial capital and operating costs (Y. S. Ho., 2004, Crini, G., 2006, Abdel et al., 2007). Bentonite is a common natural cation exchanger (Espantaleo'n et al., 2003) and According to (Ozcan and Ozcan., 2004), the specific BET surface area and surface acidity, lowest pore volume and lowest average pore size can be easily and significantly increased by acid activation, therefore both natural bentonite and acid activated bentonite were of high significant compare to all other adsorbents available. However, from a review of literature shows that there is little available information on the combination of adsorption and chemical precipitation in removal of heavy metals from industrial effluents. Hence the objective of this work is to investigate the effect of hydrogen peroxide $\left(\mathrm{H}_{2} \mathrm{O}_{2}\right)$ in combination with activated bentonite clay on the removal of heavy metal ions in industrial wastewater effluent.

\section{Preparation of Adsorbent}

Bentonite is absorbent Aluminium phyllosilicate generally impure clay consisting mostly of Montmorillonite and related clay minerals of the smeetite group, which are characterized by a large surface area per unit of weight and high Cation Exchange Capacity (CEC), (Ozcan and Ozcan., 2004). The bentonite clay sample was dispersed in the distilled water, the dispersed clay was stirred and allowed to settle and the upper layer which consists of particles was sieved off. The lower layer was continuously stirred and sieved off until it become free from suspended particles. The dispersed clay was allowed to settle for $24 \mathrm{hrs}$ to allow the sedimentation process The top layer was collected via decantation and the remainder was washed with distilled water, allowed to settle for $24 \mathrm{hrs}$ (for further sedimentation) and decanted to collect the top layer. The sol (prepared bentonite clay) was dried under the sun for several days, 
pulverized and sieved using $100 \mu \mathrm{m}$ mesh size to obtain clay of less than $100 \mu \mathrm{m}$ particle size. $150 \mathrm{~g}$ of prepared bentonite clay was mixed with $200 \mathrm{ml}$ of $2 \mathrm{M} \mathrm{HNO}_{3}$ solution for acid activation of clay in a $1000 \mathrm{ml}$ beaker. The mixture was stirred and diluted with distilled water up to $800 \mathrm{ml}$ mark of the beaker and was allowed to settle for $24 \mathrm{hrs}$. The aqueous phase was gently decanted. The acid treated or modified bentonite clay was placed in a crucible and oven dried for $3 \mathrm{hrs}$ at a temperature of $180-200^{\circ} \mathrm{C}$. The dried activated bentonite clay was pulverized and sieved using $100 \mu \mathrm{m}$ mesh size.

\section{Materials and Methods}

\subsection{Materials}

All glassware was calibrated before use and all reagents used were analytical grade obtained from Adfolak Nigeria Enterprise, Ibadan, Nigeria. All glassware and containers used were washed with acid water and distilled water before used to avoid cross contamination. Distilled water was used throughout the study.

\subsection{Methods}

Industrial effluent from a pharmaceutical industry in Ibadan, Nigeria was collected at the point of discharge into the stream after the production time. Materials used for sample collection were pretreated by washing the container with dilute hydrochloric acid and rinsed with distilled water. The containers were later dried in an oven (Model LR-271C) for 2 hours at $120 \pm 3{ }^{\circ} \mathrm{C}$ and allowed to cool to ambient temperature. At the collection point, containers were rinsed with samples thrice and then filled with the sample, corked tightly and taken to the laboratory for treatment and analysis. The longitude and latitude were taken as N $07^{\circ} 23^{\prime} 59.50^{\prime \prime}$ and $\mathrm{E} 003^{\circ} 58^{\prime} 0.40^{\prime \prime}$ at the sample point collectively. The $\mathrm{pH}$ and temperature of the wastewater sample at the collection point were 10.40 and $30^{\circ} \mathrm{C}$ respectively using (Mudder 0.01 readout accuracy digital pocket pen type, Backlit LCD.0.00$14.00 \mathrm{pH}$ meter).

\subsubsection{Wastewater Sample Digestion and Analysis}

Wet digestion was employed using $250 \mathrm{ml}$ of the wastewater sample with $10 \mathrm{ml}$ of concentrated $\mathrm{HNO}_{3}$ for $3 \mathrm{hrs}$ till the volume of the reaction mixture was reduced to about $30 \mathrm{ml}$ on a hot plate magnetic stirrer (2 LTR Capacity with 220/110 Volt). It was then filtered while hot with Whatman No 4 filter paper, and the volume made up to $50 \mathrm{ml}$ with distilled water. The metals in the digested sample were determined using flame Atomic Absorption Spectrophotometer (AAS) (Model: buck scientific VPG210) with a hollow cathode lamp and a fuel rich flame (air acetylene). Sample was aspirated and the mean signal response recorded at each of the elements wavelength heavy metals concentration in $\mathrm{mg} / \mathrm{l}$ such as iron, zinc, copper, lead, cobalt, nickel, manganese, chromium and cadmium in the sample was determined but only iron, zinc and nickel were detected from the wastewater.

\subsubsection{Wastewater Treatment}

A. Precipitation of metal ions using Alum Solution: A sample of the wastewater was divided into five portions of equal volumes $(250 \mathrm{ml})$ labelled $\mathrm{A}_{1}, \mathrm{~A}_{2}, \mathrm{~A}_{3}, \mathrm{~A}_{4}$ and $\mathrm{A}_{5}$. The first portion was further divided into five equal volumes (50ml) labelled $\mathrm{A}_{11}, \mathrm{~A}_{12}, \mathrm{~A}_{13}, \mathrm{~A}_{14}$, and $\mathrm{A}_{15}$ and each of the volume was treated with $25 \mathrm{ml}$ of standard alum solution of varying volume $(5,10,15,20$ and 25$) \mathrm{ml}$. This was done to assess clarification and sedimentation by precipitation of complex ions. Each of the five volumes (chemical and samples) was mixed slowly using a mechanical device for 30 mins to create good sample-chemical contact. After this, they were filtered individually through a bed of $5 \mathrm{~g}$ of activated bentonite clay. The clarified effluent were collected and analysed; $\mathrm{Zn}, \mathrm{Fe}$, and $\mathrm{Ni}$ were measured. Blank sample was prepared by adding Standard Alum solution and distilled water, and the resulting solution was analysed.

B. Study of the effect of $\mathrm{H}_{2} \mathrm{O}_{2}$ dose: The second experiment on the sample was done by dividing the sample, $\mathrm{A}_{2}$ into five equal volumes labelled $\mathrm{A}_{21}, \mathrm{~A}_{22}, \mathrm{~A}_{23}, \mathrm{~A}_{24}$ and $\mathrm{A}_{25}$ and treating each of the samples with Alum concentration with maximum percentage removal in wastewater treatment $\mathrm{A}$ above with the addition of $25 \mathrm{ml}$ of standard volume of $\mathrm{H}_{2} \mathrm{O}_{2}$ solution of $30 \%$ concentration to oxidize heavy metals ion present, oxidize both organic and inorganic pollutants present and to improve their adsorption, filtration, or precipitation from wastewaters. Each of the five portions of the sample was then treated with the $\mathrm{H}_{2} \mathrm{O}_{2}(0.25,0.50,0.75,1.0$ and 1.25$) \%$ volume of the effluent. The liquid content of sample- $\mathrm{H}_{2} \mathrm{O}_{2}$ mixture was agitated for 30 mins with a mechanical device for effective sample-chemical contact after which it was filtered individually through a bed of $5 \mathrm{~g}$ of activated bentonite clay. Clarified effluents were collected and analysed for $\mathrm{Zn}, \mathrm{Fe}$, and Ni parameters.

$C$ Study of contact time effect: The third portion of the effluent, $\mathrm{A}_{3}$ was divided into five equal volumes, $\mathrm{A}_{31}, \mathrm{~A}_{32}$, $\mathrm{A}_{33}, \mathrm{~A}_{34}$ and $\mathrm{A}_{35}$. Using $\mathrm{H}_{2} \mathrm{O}_{2}$ concentration with maximum percentage removal in wastewater treatment $\mathrm{B}$ above, the effect of contact time was determined by keeping the concentration of $\mathrm{H}_{2} \mathrm{O}_{2}$ constant and agitating each of the samples for 20, 40, 60, 80 and 100 mins in order to ensure effective sample-chemical contact. After this, the content was filtered individually through a bed of $5 \mathrm{~g}$ of activated bentonite clay and the resulting clarified effluent was analysed for $\mathrm{Zn}, \mathrm{Fe}$, and Ni parameters.

D Study of temperature effect: The fourth portion of the effluent, $\mathrm{A}_{4}$ was also divided into five equal volumes $\mathrm{A}_{41}$, $\mathrm{A}_{42}, \mathrm{~A}_{43}, \mathrm{~A}_{44}$ and $\mathrm{A}_{45}$. Using maximum percentage removal of $\mathrm{H}_{2} \mathrm{O}_{2}$ concentration in treatment 3.2.2. B above, time with maximum percentage removal in wastewater treatment $\mathrm{C}$ above, samples were agitated at various temperatures; 10, 20, 30,40 and $50^{\circ} \mathrm{C}$ respectively. Increasing the temperature of the reaction will almost always make the reaction go faster in removing of the heavy metals present in the effluent and help in decomposition of the $\mathrm{H}_{2} \mathrm{O}_{2}$. After this, the content was filtered individually through a bed of $5 \mathrm{~g}$ of activated bentonite clay and the resulting clarified effluent was 
analysed for $\mathrm{Zn}, \mathrm{Fe}$, and Ni parameters.

E Study of $p H$ effect: A similar procedure was carried out for the fifth portion of the sample, $\mathrm{A}_{51}, \mathrm{~A}_{52}, \mathrm{~A}_{53}, \mathrm{~A}_{54}$, and $\mathrm{A}_{55}$ and using $\mathrm{H}_{2} \mathrm{O}_{2}$ concentration with maximum percentage removal in wastewater treatment $\mathrm{B}$ above and $\mathrm{pH}$ of $4,6,8$, 10 and 12 respectively, for each of the portions in other to increase hydrolysis and precipitation of the heavy metals present in the effluent. For effective effluent-chemical contact, the mixture was agitated using the best contact time in wastewater treatment $\mathrm{D}$ above. The content was filtered individually through a bed of $5 \mathrm{~g}$ of activated bentonite clay

and the resulting clarified effluent was analysed for $\mathrm{Zn}, \mathrm{Fe}$, and Ni parameters.

\section{Result and Discussion}

Formula used in calculating percentage reduction of heavy metals in the wastewater;

Conc. of wastewater after digestion $=\mathrm{a}$

Conc. of wastewater after digestion + treatment of wastewater with activated bentonite clay \& $\mathrm{H}_{2} \mathrm{O}_{2}=$ b

Therefore,

$$
\text { percentage reduction ( } \% \text { reduction) of heavy metals }=\frac{a-b}{a} \times 100 \%
$$

Sample treatment was carried out using Alum solution for clarification while hydrogen peroxide and activated bentonite clay were used as treatment reagent.

Environmental standards for effluent limitation of World Health Organisation (WHO) and Federal Environmental Protection Agency (FEPA) are presented in Tab. 2 together with the results of the digestion analysis.

Tab. 1. Result of Analysis of the Chemical used (Blank Sample).

\begin{tabular}{llll}
\hline Chemicals & Fe(mg/l) & Zn(mg/l) & Ni(mg/l) \\
\hline Alum & nd & nd & nd \\
Distilled water & nd & nd & nd \\
\hline
\end{tabular}

nd: not detected.

Tab. 2. Physicochemical Analysis of Industrial Effluent after digestion compare to FEPA and WHO Effluent Maximum Permissible Limit.

\begin{tabular}{llll}
\hline Parameters & Concentration & $\begin{array}{l}\text { Maximum } \\
\text { Permissible }\end{array}$ & $\begin{array}{l}\text { Maximum } \\
\text { Permissible }\end{array}$ \\
\hline & $\mathbf{( m g / l )}$ & $\begin{array}{l}\text { Limit FEPA } \\
(\mathbf{m g} / \mathbf{l})\end{array}$ & $\begin{array}{l}\text { Limit WHO } \\
(\mathbf{m g} / \mathbf{l})\end{array}$ \\
\hline $\mathrm{pH}$ & 1.80 & & \\
$\mathrm{Fe}$ & 13.790 & 20 & 15 \\
$\mathrm{Zn}$ & 1.650 & $<1$ & $<1$ \\
$\mathrm{Ni}$ & 2.000 & $<1$ & $<1$ \\
\hline
\end{tabular}

Source: FEPA., 2003.

\subsection{Distribution of Heavy Metals Present in the Industrial Effluent Sample}

The concentration of selected heavy metals in the industrial effluent are represented in Tab. 2 above showing the analysis obtained from the digested sample using Flame Atomic Absorption Spectrophotometer (AAS) analysis and $\mathrm{pH}$ of the industrial effluent sample after digestion. Generally amount of heavy metals decrease from iron which had a distinct high concentration, followed by nickel to zinc which was the least metal in the study but the concentration levels of chromium, copper, lead, cobalt and cadmium were not detected in the digested effluent sample.

\subsection{Analysis of Wastewater Sample After Precipitationof Metal Ion Using Alum Solution}

The result obtained from wastewater treatment $\mathrm{A}$ in which the Alum-clarified sample at various concentrations was passed through a bed of activated bentonite clay. The results are expressed in term of the percentages of metal ion removal from the wastewater sample. The alum was used in all the experiments as coagulant aids to remove the impurities that may be dissolved or present in the effluent, as well as to remove other ions that may cause impurities in the water (Adeyinka and Rim-Rukeh., 1999). In this study, the concentration of the Alum was varied from $5-25 \mathrm{ml}$, on increasing the Alum concentration; this caused increase in the removal efficiency of the metals. At $20 \mathrm{ml}$ Alum concentration, analysis of the effluent showed a reasonable reduction given $\mathrm{Fe}^{2+}$ from 13.790 to $11.720 \mathrm{mg} / 1$ (15.01\% removal), while $\mathrm{Zn}^{2+}$ was reduced from 1.650 to $1.381 \mathrm{mg} / 1$ (16.25\% removal) and $\mathrm{Ni}^{2+}$ was reduced from 2.000 to 1.656 $\mathrm{mg} / \mathrm{l}\left(17.20 \%\right.$ removal). $\mathrm{Ni}^{2+}$ ions show a dramatical highest percentage removal due its highest structure density of $(8.908$ $\left.\mathrm{g} / \mathrm{cm}^{3}\right)$ comparing to $\mathrm{Fe}^{2+}\left(7.874 \mathrm{~g} / \mathrm{cm}^{3}\right)$ and $\mathrm{Zn}^{2+}(7.14$ $\mathrm{g} / \mathrm{cm}^{3}$ ) ion present in the effluent. Current and Structure density determines the coagulant dosage rate and the floc growth resulting in a faster removal of pollutants (Holt et al., 2002). From this study, it was found that Alum addition enhances coagulation process which is more effective at the end when the concentration is higher than at the beginning of the operation when the concentration is low which help in removing of heavy metals as they were passed through activated bentonite clay. The same observation was reported by other workers (Santarsiero et al., 1998; Tatsi et al., 2003 and Zhu et al., 2004).

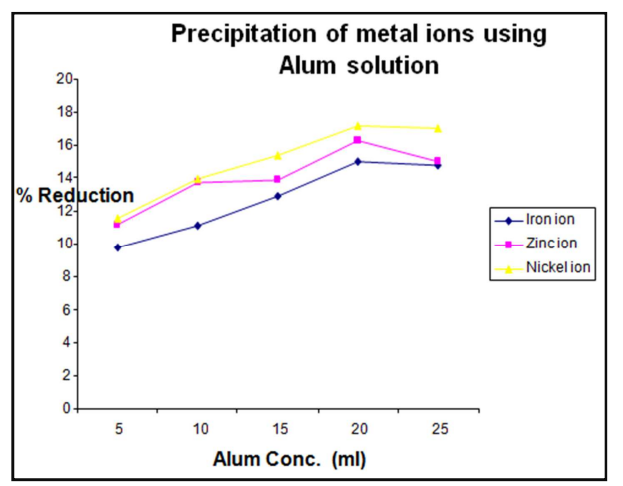

Fig. 1. Percentage reduction of effluent obtained from Alum Precipitation and treatment in bed of activate bentonite Clay. 


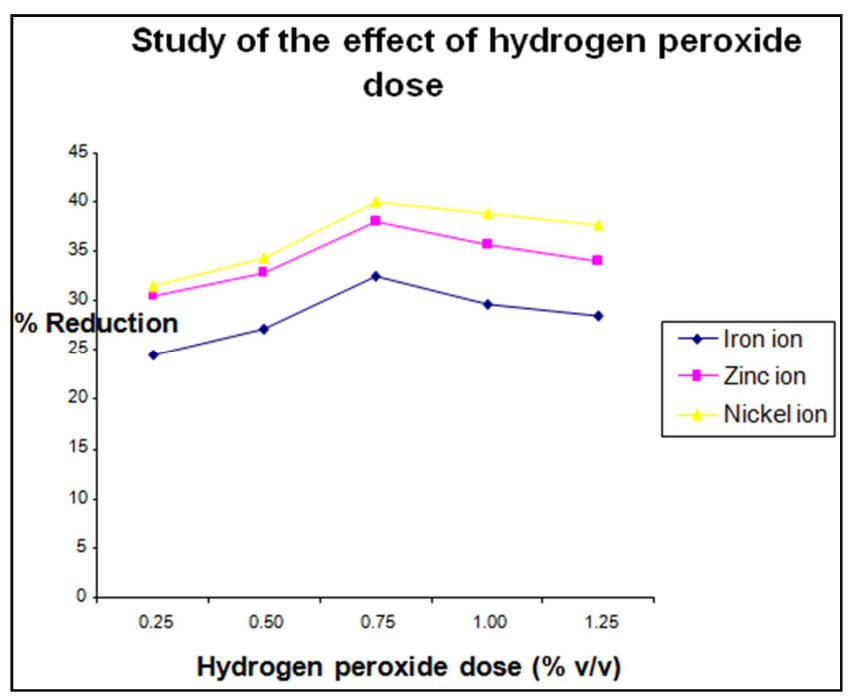

Fig. 2. Percentage reduction of effluent obtained from hydrogen peroxide and treatment in bed of activated Bentonite Clay.

\subsection{Analysis of Wastewater Sample Using Hydrogen Peroxide}

Fig. 2. shows the result obtained from wastewater treatment $\mathrm{B}$ in which $20 \mathrm{ml}$ of Alum-clarified sample was influence by $\mathrm{H}_{2} \mathrm{O}_{2}$ dose at various concentrations on wastewater effluents and then passed through a bed of activated bentonite clay. The results are expressed in term of the percentage of metal ion removal from the wastewater sample. $\mathrm{H}_{2} \mathrm{O}_{2}$ was used in the experiment to oxidize heavy metals ion present, oxidize both organic and inorganic pollutants present and to improve rate of their adsorption, filtration, or precipitation from wastewaters. $\mathrm{H}_{2} \mathrm{O}_{2}$ decomposes to give $\mathrm{H}_{2} \mathrm{O}$ and $\mathrm{O}_{2}$ which form hydroxide with the heavy metals present in the effluent sample. Analysis of the treatment and the results shows that when the concentration of hydrogen peroxide dose was increased from $0.75-1.25 \mathrm{ml}$, there is decrease in the percentage removal of the three heavy metals present in the effluent due to the availability of different side reaction, Reduction of free $\mathrm{Fe}^{2+}, \mathrm{Zn}^{2+}, \mathrm{Ni}^{2+}$ ions, this condition results to the decrease in percentage removal of the three heavy metals present in the effluent which later result to more of hydroxyl ion $\left(\mathrm{OH}^{-}\right)$in solution reacting with excess hydroxyl ion $\left(\mathrm{OH}^{-}\right)$from the decomposition of hydrogen peroxide and form hydrogen peroxide in the solution.

When the concentration of hydrogen peroxide increases above $0.75 \mathrm{ml}$, there is decrease in the absorption of the metals with the adsorbent (Rodrigez M. et al., 2002) but when the concentration of hydrogen peroxide dose was increased from $0.25-0.75 \mathrm{ml}$, there is dramatic increase in the percentage removal of all the three heavy metals present in the effluent due to more increase in ionic interaction between the metal and the hydrogen peroxide with activated bentonite clay (adsorbent) forming soluble metals which can be recovered as insoluble metal hydroxide such as $\mathrm{Zn}(\mathrm{OH})$, $\mathrm{Fe}(\mathrm{OH}), \mathrm{Ni}(\mathrm{OH})$ (Bauer R., Fallman H., 1997; Pignatello et al., 1999). From the study, on increasing the concentration dose of hydrogen peroxide to $0.75 \mathrm{ml}$ showing best reduction of $\mathrm{Fe}^{2+}$ from 13.790 to $9.311 \mathrm{mg} / 1$ (32.48\% removal), while $\mathrm{Zn}^{2+}$ was reduced from 1.650 to $1.024 \mathrm{mg} / \mathrm{l}(37.92 \%$ removal) and $\mathrm{Ni}^{2+}$ was reduced from 2.000 to $1.201 \mathrm{mg} / \mathrm{l}$ (39.95\% removal). $\mathrm{Ni}^{2+}$ has highest percentage removal on treating hydrogen peroxide due to its high solubility in hydrogen peroxide than $\mathrm{Fe}^{2+}$ and $\mathrm{Zn}^{2+}$ ions.

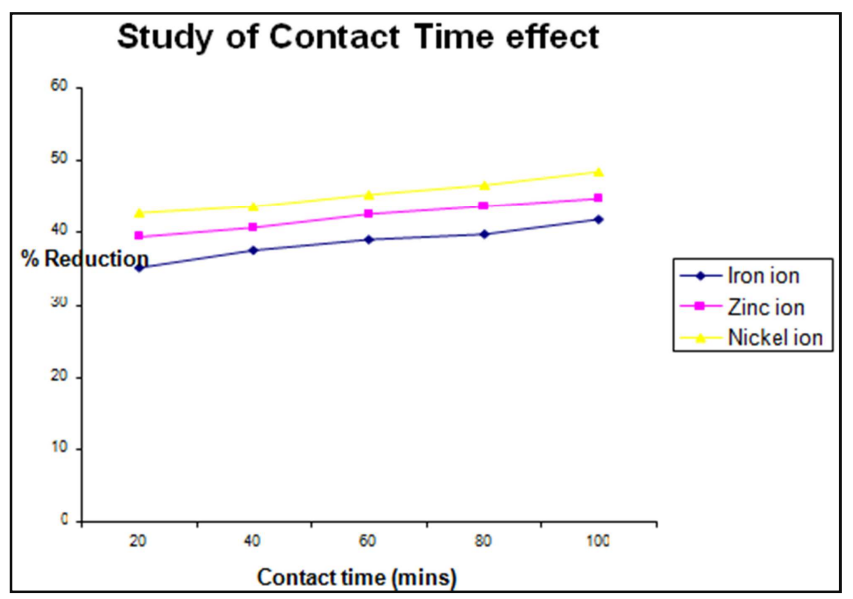

Fig. 3. Percentage reduction of effluent obtained from contact time and treatment in bed of activated Bentonite Clay.

\subsection{Analysis of Wastewater Sample Based on Contact Time Effect}

Fig. 3. shows the results obtained from wastewater treatment $\mathrm{C}$ in which $20 \mathrm{ml} / 1$ of Alum-clarified sample was influence by $\mathrm{H}_{2} \mathrm{O}_{2}$ dose at $0.75 \%$ concentration of the volume of wastewater sample showing maximum percentage removal in wastewater treatment B and agitating each of the samples for $20,40,60,80$ and 100 mins in order to ensure effective sample-chemical contact. After this, the content was filtered through a bed of activated bentonite clay and the resulting clarified effluent was analysed. Fig. 3, obviously shows that uptake of $\mathrm{Fe}^{2+}, \mathrm{Zn}^{2+}$ and $\mathrm{Ni}^{2+}$ ions by the method used with activated bentonite clay was rapid with contact time effect. Initially, the rate of removal of $\mathrm{Fe}^{2+}, \mathrm{Zn}^{2+}$ and $\mathrm{Ni}^{2+}$ ions was low because the active site on $\mathrm{H}_{2} \mathrm{O}_{2}$ and activated bentonite clay were of small time contact with the metal ions and this leads to low concentration of adsorption, but increase of contact time increases the uptake rate of the metal ions present in the effluent due high contact time between the metal ions and the active site on $\mathrm{H}_{2} \mathrm{O}_{2}$ and activated bentonite clay (Mureithi et al., 2012). Removal efficiency increased with an increase in contact time and this can be explained by the affinity of the adsorbents towards metal ions (Ramana et al., 2002). The increased uptake of all the metal ions with contact time can be due to the decreased mass transfer coefficient of the diffusion controlled reaction between the adsorbent and the metal ion (Bhattacharya A. K, et al., 2006). As contact time increases, the percentage of heavy metal removal increases drastically from 20 - 100mins showing that $\mathrm{Fe}^{2+}, \mathrm{Zn}^{2+}$ and $\mathrm{Ni}^{2+}$ ions has high affinity for the adsorbent used. However, analysis of the treatment and the results showed the best reduction at a contact time of 100 mins of 
$\mathrm{Fe}^{2+}$ from 13.790 to $8.043 \mathrm{mg} / 1$ (41.67\% removal), while $\mathrm{Zn}^{2+}$ was reduced from 1.650 to $0.910 \mathrm{mg} / 1(44.82 \%$ removal $)$ and $\mathrm{Ni}^{2+}$ was reduced from 2.000 to $1.028 \mathrm{mg} / \mathrm{l}(48.59 \%$ removal). Therefore, 100 mins contact time is recommended for $\mathrm{Fe}, \mathrm{Zn}$ and $\mathrm{Ni}$ removal from wastewater by hydrogen peroxide.

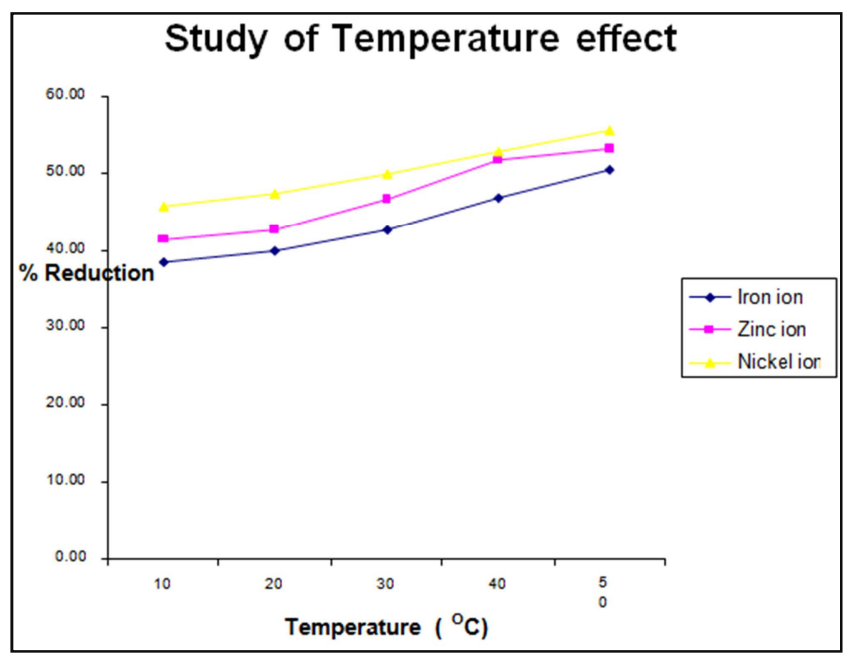

Fig. 4. Percentage reduction of effluent obtained from Temperature and treatment in bed of activated Bentonite Clay.

\subsection{Analysis of Wastewater Sample Baesd on Temperature Effect}

Fig. 4. shows the results obtained from wastewater treatment $\mathrm{D}$ in which $20 \mathrm{ml} / \mathrm{l}$ of Alum-clarified sample was influence by $\mathrm{H}_{2} \mathrm{O}_{2}$ dose at $0.75 \%$ concentration of the volume of wastewater sample showing maximum percentage removal in wastewater treatment $\mathrm{B}$ and agitating each of the samples for 100 mins at various temperatures; $10,20,30,40$, and $50^{\circ} \mathrm{C}$, respectively to make the reaction go faster in removing of the heavy metals present in the effluent and help in decomposition of the $\mathrm{H}_{2} \mathrm{O}_{2}$. After this, the content was filtered through bed of activated bentonite clay, and the resulting effluent was analysed. Increase in temperature brings about increase in adsorption rate as shown in Fig. 4. As the temperature increases, the percentage of heavy metal removal increases rapidly from $10-50^{\circ} \mathrm{C}$ respectively. Removal efficiency increases with an increase in temperature and this can be explained due to the fact that decomposition of $\mathrm{H}_{2} \mathrm{O}_{2}$ is favoured by increasing temperature (K. Akhtar, 2009). Analysis of the treatment and the result show a good reduction at $50^{\circ} \mathrm{C}$ of temperature to give $\mathrm{Fe}^{2+}$ from 13.790 to $6.820 \mathrm{mg} / \mathrm{l}$ (50.54\% removal), while $\mathrm{Zn}^{2+}$ was reduced from 1.650 to 0.771 $\mathrm{mg} / \mathrm{l}\left(53.24 \%\right.$ removal) and $\mathrm{Ni}^{2+}$ was reduced from 2.000 to $0.866 \mathrm{mg} / 1$ (55.68\% removal). The increase in percentage removal of $\mathrm{Fe}^{2+}, \mathrm{Zn}^{2+}$ and $\mathrm{Ni}^{2+}$ ion at this temperature $\left(50^{\circ} \mathrm{C}\right)$ may be possible due to the abundance of $\mathrm{OH}^{-}$ions causing increased hindrance to diffusion of metal ions (Ozer and Ozer, 2003). Increase in temperature increases adsorption for $\mathrm{Fe}^{2+}$, $\mathrm{Zn}^{2+}$ and $\mathrm{Ni}^{2+}$, This result indicate that the chemical precipitation and adsorption of $\mathrm{Fe}^{2+}, \mathrm{Zn}^{2+}$ and $\mathrm{Ni}^{2+}$ ions is endothermic in nature (Jaman et al., 2009).

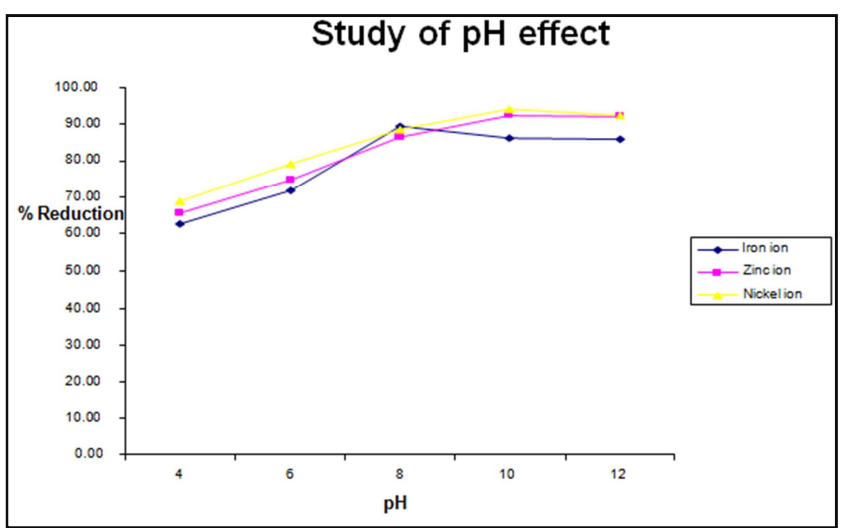

Fig. 5. Percentage reduction of effluent obtained from $\mathrm{pH}$ and treatment in bed of activated Bentonite Clay.

\subsection{Analysis of Wastewater Sample Based on PH Effect}

Fig. 5. shows the result obtained from wastewater treatment $\mathrm{E}$ in which $20 \mathrm{ml} / 1$ of Alum-clarified sample was influence by $\mathrm{H}_{2} \mathrm{O}_{2}$ dose at $0.75 \%$ concentration of the volume of wastewater sample showing maximum percentage removal in treatment $\mathrm{B}$ and agitating each of the samples for 100 mins at temperatures of $50^{\circ} \mathrm{C}$, and taken the $\mathrm{pH}$ of each sample at $\mathrm{pH}$ of $4,6,8,10$ and 12 , respectively in other to increase hydrolysis and precipitation of the heavy metals present in the effluent. After this, the content was filtered through bed of activated bentonite clay, and the resulting effluent was analysed. The effect of $\mathrm{pH}$ on the adsorption of $\mathrm{Fe}^{2+}, \mathrm{Zn}^{2+}$ and $\mathrm{Ni}^{2+}$ is presented in Fig. 5. $\mathrm{pH}$ is an important factor in adsorption chemistry of aqueous metal ions because of its influence on aqueous metal ion speciation and surface characteristics of adsorbent (Shiundu et al., 2012). The $\mathrm{pH}$ of the aqueous solution is an important operational parameter in the adsorption process because it affects the solubility of the metal ions, concentration of the counter ions on the functional groups of the adsorbent and the degree of ionization of the adsorbate during reaction (Amuda, O. $\mathrm{S}$ et al., 2007). The active sites on an adsorbent can either be protonated or deprotonated depending on the $\mathrm{pH}$ while at the same time the adsorbate speciation in solution depends the on $\mathrm{pH}$ too.

Generally, metal ions are more soluble at lower $\mathrm{pH}$ values and this enhances their adsorption as previously reported by Olayinka et al. (2009). At a pH value of 4, low metal ion uptake is observed for $\mathrm{Fe}^{2+}, \mathrm{Zn}^{2+}$ and $\mathrm{Ni}^{2+}$ ions. The use of $\mathrm{pH}$ 4 may result in the competitive adsorption of the hydrogen ion $\left(\mathrm{H}^{+}\right)$and three metal ions on the hydrogen peroxide and the activated bentonite clay surface. At $\mathrm{pH} \mathrm{4}$, the adsorbent is positively charged and hence offers repulsive force to approaching the metal ions. However, more $\mathrm{Fe}^{2+}, \mathrm{Zn}^{2+}$ and $\mathrm{Ni}^{2+}$ ions uptake is observed as the $\mathrm{pH}$ increases which is due to the fact that at high $\mathrm{pH}$ values, $\mathrm{Fe}^{2+}, \mathrm{Zn}^{2+}$ and $\mathrm{Ni}^{2+}$ ions still has a net positive charge but exists as $\mathrm{FeOH}^{+}, \mathrm{ZnOH}^{+}$and $\mathrm{NiOH}^{+}$while most active sites on the adsorbent are deprotonated. This leads to net attractive force that is responsible for high $\mathrm{Fe}, \mathrm{Zn}$ and Ni removal from solution in the alkalinic $\mathrm{pH}$ range. This results shows that with increase in $\mathrm{pH}$ of wastewater from 8-12 respectively for $\mathrm{Fe}^{2+}$ and 10-12 for $\mathrm{Zn}^{2+}$ 
and $\mathrm{Ni}^{2+}$ ions, the extent of removal of metal ion decreases. This decrease may be due to the formation of soluble hydroxyl complexes. But from $\mathrm{pH} 4-8$, there is increase in removal for all three metal ions and with increasing $\mathrm{pH}$, electrostatic repulsion decreases due to reduction of positive charge density on the sorption sites thus resulting in an enhancement of metal adsorption (Bhattacharya A K et al., 2006). From the analysis of the treatment, the results showed a good reduction at $\mathrm{pH}$ of 8 for $\mathrm{Fe}^{2+}$ to reduced $\mathrm{Fe}^{2+}$ from 13.790 to $1.436 \mathrm{mg} / \mathrm{l}(89.58 \%$ removal), while $\mathrm{Zn}^{2+}$ and $\mathrm{Ni}^{2+}$ show a good reduction at $\mathrm{pH} 10$ to give good reduction of $\mathrm{Zn}^{2+}$ from 1.650 to $0.127 \mathrm{mg} / \mathrm{l}$ $\left(92.30 \%\right.$ removal) and $\mathrm{Ni}^{2+}$ was reduced from 2.000 to 0.115 $\mathrm{mg} / \mathrm{l}\left(94.22 \%\right.$ removal). $\mathrm{Fe}^{2+}$ which should be precipitated at pH 8 in accordance to literature (xinchao., 2005). The reason for precipitation across the $\mathrm{pH}$ range may be due to progressive oxidation of $\mathrm{fe}^{2+}$ to $\mathrm{fe}^{3+}$ by oxygen in the air and its precipitation in form of $\mathrm{Fe}(\mathrm{OH})_{3}$. This tremendous increase in percent reduction of metal ions with increase in $\mathrm{pH}$ up to 8 for $\mathrm{Fe}^{2+}$ and $\mathrm{pH} 10$ for $\mathrm{Zn}^{2+}$ and $\mathrm{Ni}^{2+}$ is due to the fact that decomposition of $\mathrm{H}_{2} \mathrm{O}_{2}$ is favoured by increasing $\mathrm{pH}$ especially at $\mathrm{pH}$ 6-8 for $\mathrm{Fe}^{2+}$ and 8-10 for $\mathrm{Zn}^{2+}$ and $\mathrm{Ni}^{2+}$ (Pignatello J., Oliveros E., Mackay A., 2006). Removal of metal ions at higher $\mathrm{pH}$ values could be attributed to the formation of their hydroxide which results in precipitation, this is consistence with observation of Xiao and Ju-Chang., 2009).

\section{Conclusion and Recommendation}

In conclusion this study has revealed that there are much of heavy metals present in wastewater released by the pharmaceutical industry studied and likewise the study shows that heavy metals such as zinc $(\mathrm{Zn})$ and nickel $(\mathrm{Ni})$ released by the industry examined have high concentration of 1.650 $\mathrm{mg} / \mathrm{l}$ and $2.000 \mathrm{mg} / \mathrm{l}$ respectively which are higher than 1 $\mathrm{mg} / \mathrm{l}$ of effluent standard stipulated by Federal Environmental Protection Agency of Nigeria (FEPA) and World Health Organization (WHO), with the exception of iron $(\mathrm{Fe})$ which has low concentration of $13.790 \mathrm{mg} / \mathrm{l}$ compared to $20 \mathrm{mg} / \mathrm{l}$ effluent standard stipulated by the Federal Environmental Protection Agency of Nigeria (FEPA).

The study clearly shows that combination of hydrogen peroxide and activated bentonite clay respectively can be used effectively as adsorbent for removal of $\mathrm{Fe}^{2+}, \mathrm{Zn}^{2+}$ and $\mathrm{Ni}^{2+}$ from pharmaceutical effluent. Removal of heavy metals in effluent was optimum at $\mathrm{pH} 10$ for zinc ( $\mathrm{Zn})$ and nickel (Ni) and at $\mathrm{pH} 8$ for iron $(\mathrm{Fe})$, at temperature of $50^{\circ} \mathrm{C}, 0.75 \%$ hydrogen peroxide concentration dose and 100 minutes holding time, reducing the amounts from 13.790 to 1.436 $\mathrm{mg} / \mathrm{l}$ of $\mathrm{Fe}$, while 1.650 to $0.127 \mathrm{mg} / \mathrm{l}$ of $\mathrm{Zn}$ and 2.000 to $0.115 \mathrm{mg} / \mathrm{l}$ of $\mathrm{Ni}$. The percentage differences in concentration for the heavy metals removal in industrial wastewater are as follows: $\mathrm{Fe}(89.58 \%), \mathrm{Zn}(92.30 \%)$ and $\mathrm{Ni}$ (94.22\%). The removal of heavy metals; $\mathrm{Fe}, \mathrm{Zn}$ and $\mathrm{Ni}$ using combination of $\mathrm{H}_{2} \mathrm{O}_{2}$ and activated bentonite clay was found to be effective and was enhanced based on $\mathrm{pH}$ effect causing increase in the breaking down of $\mathrm{H}_{2} \mathrm{O}_{2}$ molecule to $\mathrm{H}_{2} \mathrm{O}$ and $\mathrm{O}_{2}$. The results obtained show that combination of hydrogen peroxide and activated bentonite clay can be used effectively in the removal of heavy metal ions from industrial wastewaters.

It is therefore recommend that from the results obtained in this study and field observation during sampling, the following recommendation are been offered;

- Industries which have some heavy metals at levels above the FEPA and WHO permissible limits in their effluents should employ more rigorous methods for the treatment of their effluents before discharge to the environment.

- Heavy metals are not the only pollutants in industrial effluents. Constant environmental monitoring should be encouraged checking the levels of other pollutants present in these effluent to ensure compliance with acceptable standards.

- Government should enforce the sound environmental disposal of industrial effluents since most of these industries carelessly dispose this wastewater into open land and waterways.

- Manufacturing industries should employ the services of quality control personnel to check the pollution load of their effluents before disposal to the environment.

- The assessment of trace organic and microbial pollutants in this effluent may be an area of further research in this study.

\section{References}

[1] Abasi, C., Abia, A. and Igwe, J. 2011. Adsorption of iron (III), lead (II) and cadmium (II) ions by unmodified raphia palm (Raphiahookeri) fruit endocarp. Environmental Research Journal, 5: 104-113.

[2] Abdel, N., Hefny, M. and Chaghaby, G. 2007. Removal of lead from aqueous solution using low cost abundantly available adsorbents. International Journal Environmental Science Technology, 1: 67-73.

[3] Adeyinka J. S, Rim-Rukeh A. 1999. Effect of Hydrogen Peroxide on Industrial wastewater effluent: A case study of Warri refining and Petrochemical Industry. Environ. Monitoring and Assessment 59: 249-256PP.

[4] Amuda, O. S., A. A. Giwa, and I. A. Bello. 2007. Removal of heavy metal from industrial wastewater using modified activated coconut shell carbon. Biochemical Engineering Journal 36: p. 174-181.

[5] Bhattacharya A. K, Mandal S. N, Das S. K, 2006. Adsorption of $\mathrm{Zn}$ (II) from aqueous solution by using Different adsorbents. Chemical Engineering Journal, 123: 43-51pp.

[6] Bauer R., Fallman H. 1997. The Photo- Fenton Oxidation a Cheap and Efficient Wastewater Treatment Method. Res. Chem. Intermediate., 23, 341-354pp.

[7] Blanchard G, Maunaye M, Martin G 1984. "Removal of Heavy from Waters by Means of Natural Zeolites" Wat. Res. 18: 1501 .

[8] Blanco AB, Sanz B, Llama MJ, Serra JL 1999. Biosorption of heavy metals to immobilized Phormidium laminosum biomass. J. Biotechnol. 69: 227-240. 
[9] Chapman, P. M., Wang, F., Janssen, C. R., Goulet, R. R., and Kamunde, C. N. 2003. Conducting Ecological risk assessments of inorganic metals and metalloids: Current status. Hum. Ecol. Risk Asses, 9, 641-697pp.

[10] Crini, G., 2006. Non-conventional low-cost adsorbents for dye removal: a review. Bioresourc. Technol. 97 (9), 1061-1085.

[11] Davydova, S. 2005. Heavy metals as toxicants in big cities. Microchem. J., 79 1-2, 133-136pp.

[12] Deng, S., Bai, R. and Chen, P. 2003. Aminated polyacrylonitrile fibers for lead and copper removal. Chemistry of Materials, 9: 5058-5064.

[13] El-Awady MH, Sami TM. 1997. Removal of heavy metals by cement kiln dust. Bull. Environ. Contam. Toxicol. 29: 603610 .

[14] Espantaleo' n, A. G., Nieto, J. A., Ferna'ndez, M., Marsal, A., 2003. Use of activated clays in the removal of dyes and surfactants from tannery waste waters. Appl. Clay Sci. 24 (12), 105-110.

[15] FEPA (Federal Environmental Protection Agency). 2003. Guidelines to Standards for Environmental Pollution in Nigeria, FG Press Lagos Nigeria. 238p.

[16] Florea, A. M., and Büsselberg, D. 2006. Occurrence, use, and potential toxic effects of metals and metal compounds. Bio Metals, 19 4, 19-427pp.

[17] Gardea-Torresdey JL, Tiemann KJ, Gonzalez JH, Henning JA, Townsend MS. 1996. Ability of silica-immobilized Medicago sativa (Alfalfa) to remove copper ions from solution. J. Hazard Mater. 57: 29-39.

[18] Gloaguen V, Morvan H. 1997. Removal of Heavy Metal Ions from Aqueous Solution by Modified Barks" J. Environ. Sci. Health, A32: 901.

[19] Howari F, H Garmoon 2003. The relation between groundwater flow and heavy metals co-precipitation with calcium carbonate: A Remediation Approach. Seattle Annual Meeting, Geological Society of America Abstracts, 35: 186193: 404.

[20] Jaman H, Chakraborty D, Saha P. 2009. A study of the thermodynamic and kinetics of copper adsorption using chemically modified rice husk, Clean., 37, 9: 704-711pp.

[21] Jeon C, Park JY, Yoo YJ. 2001. Removal of Heavy Metals in Plating Wastewater using Carboxylated AlginicAcid,'Korean J. Chem. Eng. 18: 955.

[22] Kabata-Pendias, A. 2001. Trace elements in soils and plants, 3rd Ed., A. Kabata-Pendias and H. Pendiaseds., CRC, Boca Raton, Fla.

[23] K. Akhtar. 2009. Journal of the Chemical Society of Pakistan, 31,59 .

[24] Karthikeyan, K. Chandran, C. and Kulothangan, S. 2010. Biodegradation of oil sludge of Petroleum Waste from automobile service station using selected fungi, Journal of Ecotoxicology and Environmental Monitoring, 20(3): 225230pp.

[25] Kim SJ, Jeung SY, Moon H 1998. Removal and Recovery of Heavy Metal Ions in fixed and Semi- fluidized Beds, Korean J. Chem. Eng. 15: 37.
[26] Lee SH, Jung CH, Chung H, Lee MY, Yang JW 1998. Removal of Heavy Metals from Aqueous Solution by Apple Residues, Process Biochem. 33: 205.

[27] Lujan JR, Damall DW, Stark PC, Rayson GD, GardeaTorresdey JL. 1994. Metal ion binding by algae and higher plant tissues: a phenomenological study of solution $\mathrm{pH}$ dependence. Solvent Extr. Ion Exch. 12: 803-816.

[28] McLaughlin, M. J., Zarcinas, B. A., Stevens, D. P., and Cook, N. 2000. Soil testing for heavy metals. Commun. Soil Sci. Plant Anal., 31 11-14, 1661-1700pp.

[29] Mofa AS 1995. Plants proving their worth in toxic metal cleanup. Science 269: 302-305.

[30] Mureithi, G., Onindo, O. and Muthakia, G. 2012. Kinetic and equilibrium study for the sorption of $\mathrm{Pb}$ (II) ions from aqueous phase by water hyacinth (Eichhorniacrassipes). Bulletin of the Chemical Society of Ethiopia, 2: 181-193.

[31] Olayinka, K., Oyedeji, A. and Oyeyiola, A. 2009. Removal of chromium and nickel ions from aqueous solution by adsorption on modified coconut husk. Africa Journal Environmental Science Technology, 10: 286-293.

[32] Ozcan, A. S., Ozcan, A., 2004. Adsorption of acid dyes from aqueous solutions onto acid activated bentonite. J. Colloid Interface Sci. 276 (1), 39-46.

[33] Ozer, A. and Ozer, D. 2003. Comparative study of the biosorption of $\mathrm{Pb}$ (II), $\mathrm{Ni}$ (II) and $\mathrm{Cr}$ (VI) ions. Journal of Hazardous Material, 1: 219-229.

[34] Pignatello J., Liu D., Huston P. 1999. Evidence for an Additional Oxidant in the Photo assisted Fenton Reaction. Environ. Sci. Technol., 33, 1832-1839pp.

[35] Pignatello J., Oliveros E., Mackay A. 2006. Advanced Oxidation Processes for Organic Contaminant Destruction Based on the Fenton Reaction and Related Chemistry. Rev. Env. Sci. Tec., 3, 1-84pp.

[36] Rai, R. Tripathi, P., Vajpayee, V. and Jha, M. 2002. Bioaccumulation of toxic metals $(\mathrm{Cr}, \mathrm{Cd}, \mathrm{Pb}$ and $\mathrm{Cu})$ by seeds of Euryale ferox Salisb (Makhana). Chemosphere, 46: 267272.

[37] Ramana S, Biswas AK, Kundu S, Saha JK and Yadava RBR 2002. Effect of textile dye effluent on seed germination in some vegetable crops. Bioresou. Technol. 82, 273-275.

[38] Rodrigez M., Sarria V., Esplugas S., Pulgarin C. 2002. PhotoFenton Treatment of a Biorecalcitrant Wastewater Generated in Textile Activities: Biodegradability of the Phototreated Solution. J. Photoch. Photobio. A. 151, 129-135pp.

[39] Santarsiero, A; Veschetti, E; Donati, G; Ottaviani, M. 1998. Heavy metal distribution in wastewater from a treatment plant. Micro. Chem. J. 59: 219-227pp.

[40] Sen, R. and Chakrabati, S. 2009. Biotechnology applications to environmental remediation in resources Exploitation, Current Science, 97: 6-25pp.

[41] Sharma, R. K., and Agrawal, M. 2005. "Biological effects of heavy metals: An overview.” J. Environ. Biol., 26 2, 301313pp.

[42] Shiundu, P., Attahiru, S. and Wambu, E. 2012. Removal of Cr (III) from aqueous solutions using a micaceouspolymineral from Kenya. International Journal of Physical Sciences, 8: 1198 . 
[43] Shwarts MD, Ploethner D. 1999. Removal of heavy metals from mine water by carbonate precipitation in the Grootfontein- Omatako canal. Namibia Environ. Geol. 39: 1117-1126.

[44] Sridhara, N., Kamala, C. and Samuel, D. 2008. Assessing risk of heavy metals from consuming food grown on sewage irrigated soils and food chain transfer. Ecotoxicology and Environmental Safety, 3: 513-524.

[45] Tatsi, A. A., Zouboulis, A. I., Matis, K. A., Samara, P. 2003. Coagulation-flocculation pretreatment of sanitary land fill leachates. Chemosphere. 53: 737-744pp.

[46] WHO. 2010. Water pollutant: biological agents, Dissolves Chemicals, Non-dissolves Chemicals, Sediments, Heat, WHO CEHA, Amman, Jordan. Agency, WHO Geneva, p223.

[47] Wong, C. S. C., Li, X. D., and Thornton, I. 2006. "Urban environmental geochemistry of trace metals." Environ. Pollut. $1421,1-16 p p$.
[48] Xiao and Ju-chang., 2009 Comparison of biosorbents with inorganic sorbents for removing copper (II) from aqueous solutions. Journal of Environmental Management 90: 3105-3109

[49] Xinchao W., Roger C., Viadero J. and Karen M. 2005. Recovery of Iron and Aluminum from Acid Mine Drainage by Selective Precipitation. Environ. Eng. Sci., 22, 6, 745-755pp.

[50] Y. S. HO. 2004. selection of optimum sorption isotherm. J. Carbon, 42, 2115-2116.

[51] Zhu, K; Gamal El-Din, M; Maawad, A. K; Bromley, D. 2004. Physical and chemical processes for removing suspended solid and phosphors from liquid swine manure. Environ. Technol. 25, 1177-1187pp. 